\title{
High-potential human resource management in the place marketing system
}

\author{
Lyudmila Simonova $^{1 *}$ and Anna Zyryanova ${ }^{2}$ \\ Tyumen State University, 6 Volodarskogo Street, 625003, Tyumen, Russia
}

\begin{abstract}
Serious competition for potentially valuable workers between the management teams of the regions is currently observed. The aim of the work is to form the concept of high-potential human resource management in the system of place marketing of the region (Tyumen region was taken as an example). In the "war for talents", a region needs to compete for retaining and attracting primarily such target groups as youth and young families with children. Another significant target group is migrants - former residents of the region, who now live outside the region or country. It is this target group that is in the focus of the study, forming significant elements of the regional talent management as a system that are the ways of interaction between the talent management system and the external environment (region). The online survey, carried out for more than 100 ex-residents of Tyumen region, revealed the prospects of their participation in the regional economy and built the basis of the brand platform of Tyumen Region for this target audience. It is proposed to integrate such HR-marketing tools as EJM (Employee Journey Map), EX (Employee Experience), ERM (Employee Relationship Management) into the management system for this segment.
\end{abstract}

\section{Introduction}

Digital transformation provides great business opportunities and explosive economic growth. At the same time, technological and digital transformation is often not supported by the corresponding dynamics of labor productivity and qualitative changes in human resources, which is reflected in the well-known "productivity paradox" formulated by R. Solow based on the analysis of empirical data [1].

This gap between the technological and human factors of production is revealed in acute shortage of valuable personnel - $45 \%$ of employers in the world are not able to find a suitable employee, since there are simply no candidates on the market, who would possess the required qualifications, even in populous and rapidly developing China ("talent paradox") [2], in active headhunting of valuable personnel by competitors (executive search), in the growing imbalance between strategic jobs and the skill level and productivity of workers. According to Boston Consulting Group, more than $80 \%$ of Russia's working-age population does not have the skills and competencies to work in modern markets [3]. These resource constraints in relation to the quality and supply of human resources in Russia are aggravated by the consequences of the "demographic and qualification hole", long-term brain drain to foreign countries - according to RANEPA, 100,000 people leave Russia every year, $40 \%$ of which have higher education
[2], an increase in the degree of differentiation of regions and an increase in interregional competition for investment and human resources.

Availability of qualified labor is becoming a systemic advantage that determines the interest of investors in the region. In the struggle for personnel, their training and retention, there is a serious competition between the managerial teams of the regions. Proof may be found in the results of the survey of the employees who work in American companies in Russia, conducted by the American Chamber of Commerce in partnership with the EY company. Among companies planning to expand their regional presence $(30 \%$ of the total number of respondents), the main selection criterion is the availability of qualified personnel $(25 \%)$ - this indicator outweighed the proximity to large sales markets (19\%), the position of the region in the ranking of investment climate (17\%), a developed transport system and personal support of the governor (14\% each), tax conditions and benefits (8\%). [4].

Both in the world and in Russia a real "war for talent" is unfolding. At the meso-level, this war acquires its own characteristics, but does not reduce its intensity. It is driven by digital transformation, the growing demand for talent and for the mobility of skills. In these circumstances, the task of regional governments is to develop mechanisms for the preservation, retention, accumulation, development and reproduction of human capital on their territory, which is especially important in relation to high-potential human resources.

\footnotetext{
* Corresponding author: 1sim@utmn.ru
} 
In this regard, the purpose of the work is to form the framework (concept) of high-potential human resources management in the regional system of territorial marketing.

\section{Materials and Methods}

Research in the field of organizational theory, strategy and economic development are focused on how the total human capital of a unit, a company, or the economy turns into a competitive advantage at the level of the firm and provides economic development $[5 ; 6]$. In this regard, the general scientific task at which the research is aimed is to study the mechanisms of how human capital influences the socio-economic development of regions. The main reason for this focus is the growing awareness of the fact that human resources and their interconnection are important for the activities of any actor, be it a firm, region, nation or economy. At the same time, the quality of human capital is of primary importance for the competitiveness of the regional economy. A fairly narrow group of people (economic agents) has a significant potential to influence it. Proceeding from the philosophy of human capital management, which is based on its strengths (Strengthsbased philosophy), the concept of talent management will be approached as our task is to select "economic agents", groups of people with large human capital stock. The initial theoretical base is the resource theory [7;8], which considers talent as unique and difficult-toreproduce resources used to achieve competitive advantages. It is a unique combination of individualpersonal and social characteristics that creates such resources and forms the degree of their demand (conjuncture) in the society.

The development of the problematics of talents, their specificity and special characteristics, classification and significance for the competitiveness of organizations has recently become widespread in foreign and domestic scientific literature and forms the modern agenda of global scientific research. Based on a generalization of the most authoritative sources in this area we will clarify the terminology of the basic concepts. $[9 ; 10 ; 11 ; 12 ; 13$; $14 ; 15 ; 16 ; 17 ; 18]$

Talents are high-resource workers who can improve the performance of the region either right now, through their direct contribution, or in the long term, thanks to their high potential. In the world practice, such employees are called HiPo (High Potential) and in SHRM theory they are classified as strategic capital. Consequently, our basic concepts to operate are 'talents' as special resourceful groups and 'strategic human capital' - people who can influence society, the leaders of the intellectual and social development. [19].

Scientists consider talent in a narrow sense as the leaders; or as highly potential and/or highly productive employees [14]; or, in a broad interpretation, as all employees. The broad interpretation of the concept serves best the objectives of this study.

'Talent management' is a systematic identification, involvement, development, retention and the right placement of the employees who are valuable for the region due to either their high potential for the future or to what they are able to contribute to the regional economy at present - their specific competencies or the strategic positions they hold.

Increasing competition at the local and global level makes the tasks of attracting, developing, placing and retaining employees considered as talents challenging for company management and regional authorities $[21 ; 11$; $14 ; 20 ; 22 ; 23]$.

Traditionally, talent management has been viewed in relation to a firm or organization. But the research of the whole logical chain from forming individual KSAO («Knowledge, skills, abilities, and: other characteristics») of HiPo employees (nanolevel) to converting them into a competitive advantage of the firm, the industry and the region on the micro and meso levels is of interest [6]. At the same time, the return on human capital, its social performance, that is, the impact on the development and competitiveness of the region, is of fundamental importance.

For this study, the meso- and micro- levels are the most significant for the creation, reproduction and development of strategic human capital. Consequently, the objects of research are economic agents (firms, organizations, individuals), especially, HiPo-employees, and a region as a space of places for the implementation of dominant functions in the network society (according to M. Castells: financial markets, transnational production networks, information networks, network forms of management, social movements). It is the region that provides this space of places and creates an environment for the formation, accumulation and reproduction of strategic human capital. In connection with this study it is essential to take into account regional context, i.e. the combination of environmental factors affecting talent management [24]. This regional context acts as a prerequisite and the result of the strategic management of human capital [25].

This aspect, defining methodological specifics of the study, and reflecting the interaction of the regional environment and talent management, is implemented in the system of place marketing. The basic theoretical aspects of territorial marketing and branding are developed in the writings of scholars such as F. Kotler, S. Anholt, S. Raynisto, P.-P. Perre, M. Andersson, G. Trout, A. Rice et al. [26; 27; 28]

Recently, the era of employee power has entered the human resources market. The same applies to highpotential residents of regions, especially provincial ones. The main factor of choice is the region's prospects in terms of opportunities for self-realization and ensuring the required standard of living. Thus, the territory becomes, on the one hand, a product that, as marketers say, must be "well packaged" in order to become attractive to potential "customers", and on the other hand, a brand with a well-thought-out communication system.

Interregional competition is unfolding for target groups of consumers of resources, who, in their turn, contribute to the development of the region, attracting new resources (people, funding, capital, information) to 
the region. Tightening of interregional competition - one of the threats already existing objectively - makes it necessary to integrate tools of place marketing into the system of the region's competitiveness management. In terms of managing such a segment of the target audience as human resources with high potential, HR marketing tools are most suitable, namely EJM (Employee Journey Map), EX (Employee Experience), ERM (Employee Relationship Management).

The most important area of competition in the region is the preservation and attraction of human resources. The regional context is studied using the example of the Tyumen region.

Former residents of the region who moved from Tyumen region to other regions of Russia and other countries were selected as the object for this study. The survey was conducted online by filling out a Google survey form, and 101 respondents participated in the survey. The purpose of the survey is to assess the possibility of interaction between Tyumen region and this target group, to explore the prospects for the participation of representatives of this segment of target group "Talents" in the regional economy and form the basis of the Tyumen region brand platform for this segment of the target audience. The objectives of the survey were as follows:

- to compile a socio-demographic portrait of the respondents (gender, age, marital status, educational level, the nature of professional activity, participation in ensuring subsistence)

- to track the geography of the outflow (from which settlement of Tyumen region the person moved, how many years ago, where he moved initially);

- to assess the level of satisfaction of respondents with their current life (quality of life, level of income);

- to identify the presence/absence of connections with Tyumen region at the moment (questions: Is your current occupation connected with Tyumen region?; Do you have any close relatives in the Tyumen region?; Do you keep in touch with the residents of Tyumen region? How often do you come to Tyumen region?)

- to find out the motives of migration;

- to assess the current opinion about Tyumen region;

- to analyze the factors of attractiveness of Tyumen region as a territory of permanent or temporary stay (questions: What was the main motive for your move? Would you recommend Tyumen region for visiting and living? How would you describe Tyumen region for those who have no idea about it?)

Although the data are still being analysed at the moment, the results obtained for each of the groups of questions allowed us to draw some conclusions.

\section{Research Results}

The bulk ( $71 \%$ of the respondents) were people aged 31 to 45 years. $24 \%$ - the age group 20-30 years old, $5 \%$ people over 45 years old. Women accounted for $74 \%$ of the total number of respondents, men - $26 \%$. This group of respondents can fully represent the target group "Talents", because $57 \%$ of the respondents have one higher education, $29 \%$ have more than one higher education, $8 \%$ have a candidate of sciences $/ \mathrm{PhD}$ degree, $1 \%$ have a doctor of sciences degree, 5\% have incomplete higher education (currently they are university students). According to their occupations, the respondents were divided into the following groups: $24 \%$ - office work, $19 \%$ - work in a non-governmental institution; $15 \%$ - work in a state institution; $13 \%$ entrepreneurs, $9 \%$ - self-employed; $6 \%$ - creative industries; $2 \%$ - researchers; $8 \%$ do not work; $4 \%$ are studying. At the same time, $77 \%$ support their existence independently; $23 \%$ depend on spouses or parents.

Thus, we see that only $8 \%$ of respondents do not work, $92 \%$ are actively involved in various spheres of the economy, which means they acquire valuable experience and develop their human potential.

In order to understand the trends in the geography of migration, the sample should certainly be larger, however, and it allows us to draw some conclusions. In total, $64 \%$ were interregional migration $(25 \%$ moved to Moscow, 9\% - to St. Petersburg, 6\% - to Kasnodar region, $6 \%$ - to Yekaterinburg; $4 \%$ - to the north (Khanty-Mansi Autonomous Okrug-Yugra and YamaloNenets Autonomous Okrug); regions of the central Russia - 4\%, regions of Russia to the east of Tyumen region - 3\%, Tatarstan - 2\%, Crimea - 1\%). Among the countries attractive for relocation are the European countries (22\%). 3\% of respondents moved to North America (USA, Canada), $8 \%$ - to other countries of the world (Armenia, UAE, Egypt, Turkey, China, South Africa).

An important fact is that most people planning a move consider other regions of Russia, while former Tyumen residents are mainly attracted by Moscow, St. Petersburg, Krasnodar region, Yekaterinburg, and the north (Khanty-Mansi Autonomous Okrug and YamaloNenets Autonomous Okrug). It is with these regions that it is necessary to build a competitive strategy for Tyumen region. It is quite obvious that Krasnodar region and warm countries attract Tyumen residents primarily for their climate.

Tyumen cannot compete with the capitals at the moment either in terms of the level of development of the creative environment (some respondents note that Tyumen is "boring", "nothing to do there", "nowhere to go"), or in terms of income. The same is with the countries of Europe and North America, where even a higher level of comfort and infrastructure development is observed. Accordingly, the only correct strategy of interaction with these regions and countries will not be competition, but partnership. In particular, the involvement of migrants in the activities of the region should be implemented remotely. In our opinion, this is an underestimated resource of Tyumen region.

Firstly, $100 \%$ of respondents keep in touch with friends and former colleagues - residents of Tyumen region, $97 \%$ have close relatives in Tyumen region, only $5 \%$ do not come to Tyumen region since they moved, the rest regularly come $(38,2 \%$ - more than 2 times a year, $38.2 \%$ - not more than once a year, $18.6 \%$ - once in several years). 
Secondly, the majority of respondents demonstrated loyalty, describing their native region, and would recommend to visit Tyumen region to those, who has never been there, at least as tourists. And many say that if you want to work in the oil and gas industry, realize yourself in entrepreneurship, it is worth coming and living in Tyumen and the region, as it is "a rich, dynamic region with gorgeous nature", "like Moscow, only smaller", "a provincial cozy city that has everything for a happy life", "a beautiful Siberian region with a good university".

Thirdly, many called local residents "the main advantage" of Tyumen region. "Kind, easy-going, very adequate, modern, cool, talented, strong-willed, caring people who strive for development and will always come to the rescue" - such a collective image of the inhabitants of the Tyumen region was formed from the answers to the question: "How would you describe Tyumen region to those who have no idea about it?" In general, it should be noted that many of the answers were detailed and sincere, which reflected general positive attitude of the respondents and readiness to interact with the region.

Another unexpected discovery of our study is the proximity and reach of the representatives of the studied segment of the target group "Talents", despite the distance and years of residence in other places. 75 responses were received within the first 24 hours after the survey was published, the remaining 26 responses were received within the next three days. $40 \%$ expressed interest in receiving the survey results and left their email addresses, which in today's conditions of huge information flows and widespread spam, we consider a very good indicator. $15 \%$ of the respondents offered to be interviewed if necessary, although there was no such question in the survey.

Thus, we believe that systematic work using place marketing tools that can facilitate the involvement of talent in the economy of Tyumen region and make a tangible contribution to the further development of the region, might bring fruitful results.

\section{Discussion}

To build an effective system of interaction with consumers of the target group "Talents", it is proposed to introduce a CRM system (Customer Relationship Management) as a philosophy of building long-term productive relationships with representatives of this group at different stages of their interaction with the territory. In the work "Talent beyond Capitals"[28], the authors even propose to replace the familiar term CRM with "TRM" (Talent Relationship Management) and identify five main stages of interaction between talents and the territory (see Figure1).

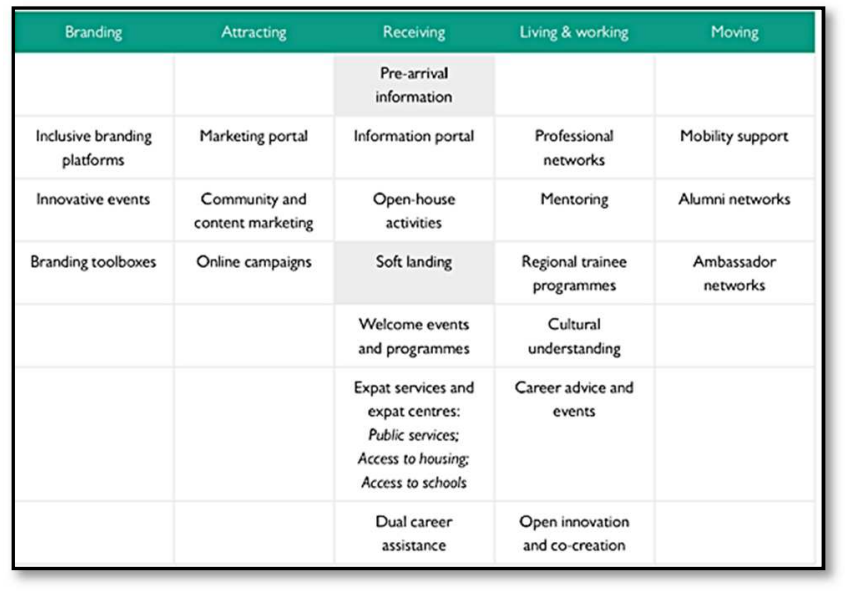

Fig. 1. Stages of interaction of the territory with talents, proposed by the author of the concept of Talent Relationship Management [28]

Talent Relationship Management - a system of managing relationship with talent - is based on the principles, identical to CRM (Customer Relationship Management). This is not just a one-time "sale", it is a system of long-term relations aimed at mutually beneficial cooperation. Currently, recruiting companies have begun to actively develop technologies for attracting talent and use ERM (Employee Relationship Management) by analogy. In the Russian practice of regional management such targeted programs do not exist yet.

Customer Journey Map (CJM) - a roadmap of a customer in CRM - consists of three main "points" stages of interaction between the company and the consumer: 1. Awareness stage; 2. Consideration Stage; 3. Decision Stage [29].

Similarly, a region should have a journey map of talent (or high-potential human resources) - the stages of interaction between territory and talent, which allows tracing the logic of "hiring" the place as a product of place marketing.

The overall strategy for creating a map of the talent journey from initial understanding to productive interaction with the territory, as well as the tactics of "guiding the talent along the route" must be adapted to the needs of each target group, combining the tools of territorial marketing in such a way that they best contribute to the achievement of marketing goals and objectives. allowed to form the desired image of the territory and led to the desired models of behavior of talents.

Key performance indicators of marketing a region in relation to the target group "Population" in general will be the following: accumulation of the population, migration inflow, growth in the wealth of citizens, a decrease in population differentiation by income level, a favorable demographic portfolio.

For the Talents segment, it is important to add such specific indicators as:

- inflow of highly qualified personnel, 
- participation of highly qualified personnel from other regions in solving the problems of socio-economic development of the target region,

- duration of stay of the talent in the territory / amount of participation in hours

- economic, social, scientific, innovative or other result of the activity of a talent in the target region during the period of stay,

- the cost of attracting and maintaining talent in Tyumen region

- the economic effect of stay for the talent (income, expenses)

- in the long term, LTV - life-time value as an indicator of loyalty - the number of projects implemented with the participation of talent in the region.

\section{Conclusion}

The basic principles of talent management that characterize their interaction with territories may be formulated as follows:

- the influx of talent in the region, equivalent to an increase of its competitiveness;

- talents are mobile, so it is not reasonable to try and keep them forever;

- the relocation of talent (migration) does not mean its complete exclusion from the economic activity of the territory;

- the reciprocity of the hiring process "talent-region": we hire them, and they hire us to realize their potential, to earn money (possibly short-term), for a comfortable life, to be able to travel, etc. The "win-win" principle should become the basis of this relationship. Both parties must win.

To build an effective system of interaction with talents it is proposed to introduce a CRM-system (Customer Relationship Management) as a philosophy of building long-term productive relationship at different stages of their interaction with the region.

The competent analysis of the region's competitiveness factors and factors of choice of a region by target groups, the use of place marketing tools that meet the requirements of each stage of the "consumer's journey", as well as the integration of a kind of CRM systems into work with consumers of a territory- whether they are tourists, talents, the population, entrepreneurs, investors - will allow regional authorities to effectively manage the behavior of target groups based on the data collected at each stage.

In post-pandemic space the consumers' behavior and the consumption of territories as products will change. There will be a reassessment of the value orientations of target groups and the competitive advantages of a particular territory, and that may result in the ability of peripheral regions to receive an inflow of high-quality human capital.

It is not always advisable to fight for the physical presence of talent on the territory. Technically, the interaction of the territory with talents in the interests of the territory is also possible at a distance. This becomes especially relevant when the talent comes from this region. According to the research, such people are the most open to suggestions, they are much easier to engage. It is they who are able to increase the competitiveness of the region.

\section{Acknowlegements}

The reported study was funded by RFBR, project number 19-29-07131.

\section{References}

1. Solow R. Rev. of Ec. and Stat., 39, 3 (1957)

2. E. Vinogradova, Vedomosti (Dec. 20, 2019)

3. A. Auzan, Novaya Gazeta, 130 (Nov. 22, 2017)

4. N. Bleiman, RBC plus, 1-2 (154), 122-127, (2020)

5. N. Gennaioli, R. L. Porta, F. L. de Silanes, and A. Shleifer, The Quart. J. of Ec., 128, 1 (2013)

6. C. E. Helfat, et al. Dynamic capabilities: Understanding strategic change in organizations (John Wiley \& Sons, 2009)

7. E. T. Penrose The Theory of the Growth of the Firm (Basil Blackwell: London, 1959)

8. J. B. Barney J. of Manag., 17, 1 (1991)

9. P. Casse, J. of Eur. Ind. Tr., 18, 5 (1994)

10. G. K. Stahl, I. Bjorkman, E. Farndale, S. S. Morris, J. Paauwe, P. Stile, Global Talent Management: How Leading Multinational Build and Sustain their Talent Pipeline (INSEAD Fontainebleau: 2007)

11. P. Cappelli, Talent on Demand: Managing Talent in an Age of Uncertainty (Boston, 2008)

12. D. G. Collings, K. Mellahi H. R. Manag. Rev., 19, 4 (2009)

13. S. Swailes, Bus. Ethics: A Eur. Rev., 22, 1 (2013)

14. N. Dries, H. R. Manag. Rev., 23, 4 (2013)

15. A. R. Malik, P. Singh, H. R. Manag. Rev., 24, 4 (2014)

16. W. F. Cascio, J. W. Boudreau, J. of W. Bus., 51, 1 (2015)

17. C. Kontoghiorghes, Int. J. of H. R. Manag., 27, 16 (2016)

18. A. McDonnell, D. G. Collings, K. Melahi, R. Schuler, Eur. J. of Int. Manag., 11, 86-128 (2017)

19. L. Czaller, Region. Stud., 51, 3 (2017)

20. I. Bjorkman, M. Ehrnrooth, K. Makela, A. Smale, J. Sumelius, H. R. Manag., 52, 2 (2013)

21. J. W. Boudreau, P. M. Ramstad, P. J. Dowling, CAHRS WP02-21 (2002)

22. P. R.Sparrow, H. Makram H. R. Manag. Rev., 25, 249-263 (2015)

23. J. H. Marler, J. W. Boudreau, Int. J. of H. R. Manag. 28, 1 (2017)

24. V. Vaiman, H. Scullion, D. Collings, Manag. Decis. 50, 5 (2012)

25. C. Brewster, Manag. Int. Rev. 39, 45-64 (1999)

26. S. Anholt, Destination Branding: Creating the Unique Destination Proposition (Oxford, 2002) 
27. S. K. Rainisto, Success Factors of Place Marketing: A Study of Place Marketing Practices in Northern Europe and the United States (Helsinki University of Technology, 2003)

28. P.-P. Pere, Talent beyond capitals. Handbook. (Stockholm: Future Place Leadership, 2018)

29. B. D. Temkin, Mapping the customer journey (Forrester Research Inc., 2010) 